\title{
Posterior reversible encephalopathy syndrome as an underlying cause for encephalopathy in a sepsis patient in the intensive care unit: A case report
}

\author{
Günseli Orhun, M.D.
}

Department of Anesthesiology and Intensive Care, İstanbul University İstanbul Faculty of Medicine, İstanbul-Turkey

\begin{abstract}
Posterior reversible encephalopathy (PRES) is a clinical and radiological syndrome characterized by neurological findings and vasogenic edema in the posterior regions of the cerebral hemispheres. Sepsis and septic shock have recently been recognized as an etiological factor in PRES. In this case report, we are presenting a patient with intraabdominal sepsis and PRES followed in the intensive care unit with an unfavorable neurological outcome. Wider recognition of PRES as a cause of encephalopathy in sepsis patients is necessary.
\end{abstract}

Keywords: Posterior reversible encephalopathy syndrome; prognosis; sepsis.

\section{INTRODUCTION}

Posterior reversible encephalopathy syndrome (PRES) is a well-recognized syndrome characterized by mental status changes, seizures, focal neurological signs and coma, initially described in acutely hypertensive patients usually with favorable clinical prognosis and reversible radiological findings. [I] The etiology list has been lengthened in many papers to comprise other underlying causes, including sepsis. ${ }^{[2,3]}$ The management of sepsis requires a multidisciplinary approach, and prompt and precise diagnosis is mandatory for treatment and favorable prognosis. With the etiology of sepsis or other causes, PRES is a very important entity for the intensivist to recognize. PRES presents with acute or subacute neurological findings and well established radiological findings. We are reporting a patient with intraabdominal sepsis and PRES with the hope that PRES gains wider recognition as a cause of encephalopathy in sepsis patients in the intensive care unit (ICU), resulting in timely treatment and better prognosis.

\section{CASE REPORT}

52-year-old female patient with hypertension, diabetes mel- litus and congestive heart failure has been admitted to the emergency unit with an acute abdomen two days after an attempt to retrieve stem cells by liposuction from the abdomen for treatment of knee osteoarthritis. Upon detection of fluid and hematoma between the bowel loops on abdominal computed tomography (CT), the patient was taken into emergency laparotomy. Multiple small bowel perforations and intestinal fluid were detected in the abdomen whereupon small bowel resection, diverting ileostomy and abdominal vacuum-assisted closure were performed. In the perioperative period, the patient was taken into the ICU with hemodynamic deterioration and hypotension unresponsive to vasopressor infusion. On admission to the ICU, laboratory workup demonstrated leucocyte count $11200 / \mathrm{mm}^{3}$, C-reactive protein $613.6 \mathrm{mg} / \mathrm{L}$, procalcitonin levels $45.5 \mathrm{ng} / \mathrm{L}$, creatinine $2.9 \mathrm{mg} / \mathrm{dL}$, serum ammonia level $33 \mathrm{mg} / \mathrm{dL}$. Liver enzymes, coagulation tests and serum electrolytes were normal. A wide spectrum of antibiotic treatment was initiated. Hemodynamic problems deteriorated further shortly after admission into the ICU, requiring a second vasopressor and hydrocortisone treatment. Hemofiltration was started upon disturbance of renal functions. Intraabdominal fluid cultures showed Kleb-

Cite this article as: Orhun G. Posterior reversible encephalopathy syndrome as an underlying cause for encephalopathy in a sepsis patient in the intensive care unit: A case report. Ulus Travma Acil Cerrahi Derg 2020;26:325-327.

Address for correspondence: Günseli Orhun, M.D. İstanbul Üniversitesi İstanbul Tıp Fakültesi, Anesteziyoloji ve Reanimasyon Anabilim Dal, 34093 İstanbul, Turkey Tel: +90 212 - 4142000 E-mail: gunseli_orhun@hotmail.com 
siella pneumonia, and a suitable antibiotic regimen was administered. On the sixth day of ICU admission, vasopressor infusion and hemofiltration were stopped. During the ICU stay, sedation was discontinued daily for neurological examination and delirium assessment with the Confusion Assessment Method for the ICU. The patient was weaned from the respirator and discharged to the ward conscious and neurologically intact state on the eleventh day of ICU admission. The patient deteriorated and developed septic shock on the ward and was re-admitted into the ICU five days after and intubated. The patient went through repeated surgical procedures for intraabdominal infection and abdominal wall defect. Neurological assessment after cessation of sedation revealed that the patient was unresponsive with no movement in four extremities and intact brain stem reflexes. Laboratory investigation during acute neurological dysfunction showed a leukocyte count of $11500 / \mathrm{mm}^{3}$, C-reactive protein $105.4 \mathrm{mg} / \mathrm{L}$, procalcitonin levels $7.6 \mathrm{ng} / \mathrm{L}$, creatinine $0.8 \mathrm{mg} / \mathrm{dL}$ and lactate dehydrogenase $419 \mathrm{U} / \mathrm{L}$. Liver function tests were slightly elevated, and coagulation tests were abnormal. Endotracheal aspirate culture revealed $K$. pneumoniae and Grampositive rods. Intraabdominal fluid cultures and blood cultures showed $K$. pneumoniae growth. A non-enhanced brain CT was unremarkable. The electroencephalogram showed a diffuse slowing of electrical activity. The cerebrospinal fluid analysis was not possible due to acquired coagulopathy. Brain magnetic resonance imaging (MRI) was possible only on the ninth day of acute neurological deterioration due to hemodynamic instability revealing cortical and subcortical vasogenic edema symmetrically in the parietal and occipital lobes extending into the temporal and frontal regions and deep white matter. Hemorrhage was present in the frontal and parietal cortex (Fig. I). The patient was diagnosed clinically and radiologically with PRES. The neurological status of the patient showed no improvement. She was weaned from the respirator, and a tracheostomy was performed. MRI scan was repeated one month later, showing the same lesion involvement with some cystic transformation in the frontal deep white matter, suggesting no radiological improvement, and on the contrary, ongoing neural tissue loss leading to cystic changes. The patient was discharged home as a care patient.

\section{DISCUSSION}

PRES is a clinical and radiological syndrome that is usually diagnosed with acute or subacute neurological findings. ${ }^{[1]} \mathrm{Neu}-$ roimaging has greatly facilitated the diagnosis of PRES, which is usually characterized by vasogenic edema in the cortical and subcortical region of parietal and occipital regions, sometimes extending into temporal and frontal lobes. Although this is the classical radiological tableau, cytotoxic edema, deep gray matter, corpus callosum and posterior fossa involvement have also been described. ${ }^{[4,5]}$ Extensive involvement and hemorrhage have been loosely correlated with a less favorable prognosis, as well as the presence of sepsis as underlying etiology. ${ }^{[6,7]}$ Clinical and radiological findings of PRES in hypertension, immunosuppressive treatment and rheumatological diseases have been shown to resolve over time, following prompt diagnosis and treatment; on the other hand, sepsis and septic shock are usually associated with worse prognosis in PRES. ${ }^{[7,8]}$

On the pathophysiological level, the cellular processes leading to PRES in sepsis are still unclear. The vasogenic theory suggesting loss of autoregulation and leakage of fluid into the interstitial space due to abrupt hypertension may not apply to the septic patient in the majority of cases. ${ }^{[8,9]}$ The endothelial damage theory hypothesizes an increase in blood pressure due to endothelial dysfunction. ${ }^{[10]}$ The immunogenic theory, which is thought to involve activation of $T$ cells and release of cytokines can be considered as the most relevant since cytokine-mediated mechanism inducing sepsis is very similar to those underlying PRES. ${ }^{[1]}$

Sepsis is a grave condition that influences the whole body and the central nervous system may be the first system involved.
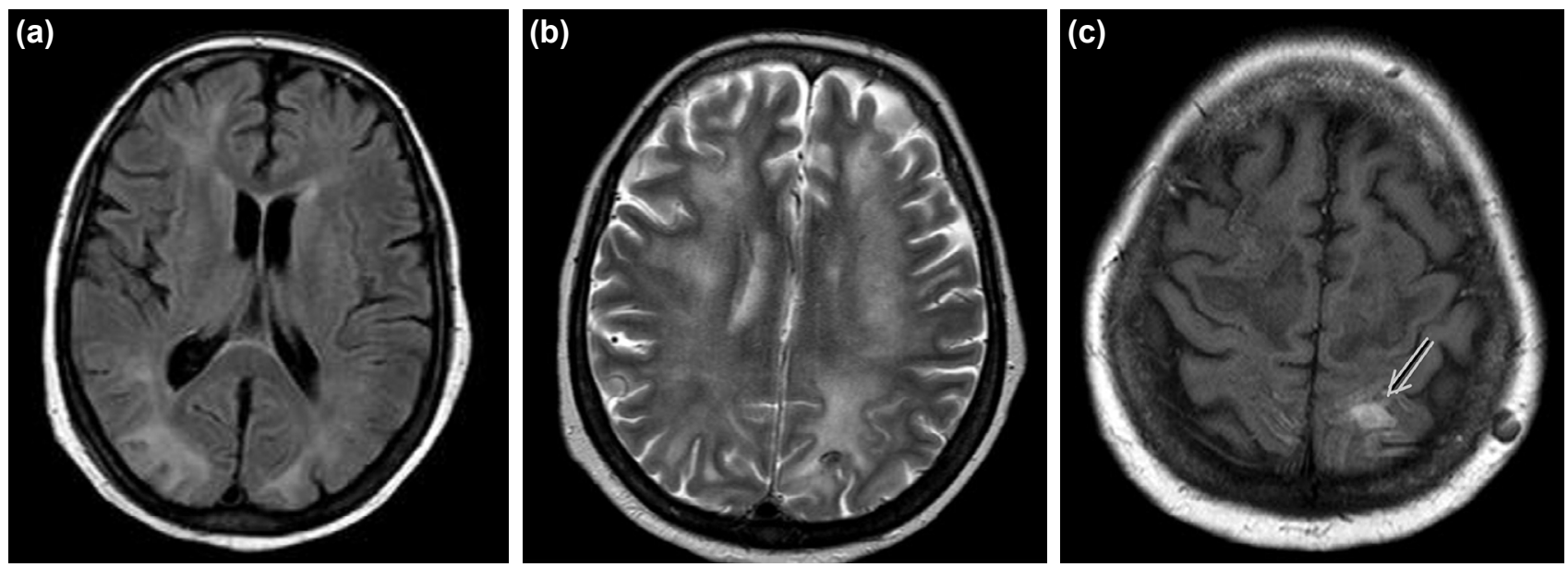

Figure 1. Representative images of posterior reversible encephalopathy syndrome (PRES). PRES findings in 52-year-old septic shock patient who developed acute neurologic deterioration. FLAIR, T2-weighted and T1-weighted axial MR images show cortical and subcortical edema extending into the deep white matter $(\mathbf{a}, \mathbf{b})$. The hyperintense region in (c) (arrowhead) depicts hemorrhage. 
${ }^{[12]}$ Although the radiology of PRES more or less follows the same pattern in most patients, a specific radiological pattern in sepsis has not been described. ${ }^{[2,3]}$ In our case, there was hemorrhage and extensive cortical, subcortical and deep white matter involvement in both hemispheres and cortical hemorrhage. These findings were irreversible with some cystic and encephalomalacic changes on the first control MRI scan. The patient never made a neurological recovery. The specific radiological findings of PRES in sepsis, reversibility and correlation with clinical findings and the reflection on prognosis remain to be determined.

Sepsis and septic encephalopathy entail the involvement of physicians from many disciplines, including critical care physicians, neurologists, neurosurgeons and general surgeons in the care of the patient. PRES is an entity that needs to be recognized by the treating team. The authors believe that well-documented case series and epidemiological studies will shed better light on PRES in sepsis patients.

Informed Consent: Written informed consent was obtained from the patient's relatives for the publication of the case report and the accompanying images.

Peer-review: Internally peer-reviewed.

Authorship Contributions: Concept: G.O.; Design: v Supervision: G.O.; Fundings: G.O.; Materials: G.O.; Data: G.O.; Analysis: G.O.; Literature search: G.O.; Writing: G.O.; Critical revision: G.O.

Conflict of Interest: None declared.

Financial Disclosure: The autors declared that this study has received no financial support.

\section{REFERENCES}

1. Fugate JE, Rabinstein AA. Posterior reversible encephalopathy syndrome: clinical and radiological manifestations, pathophysiology, and outstanding questions [published correction appears in Lancet Neurol. 2015 Sep;14(9):874]. Lancet Neurol 2015;14:914-25. [CrossRef]

2. Bartynski WS, Boardman JF, Zeigler ZR, Shadduck RK, Lister J. Posterior reversible encephalopathy syndrome in infection, sepsis, and shock. AJNR Am J Neuroradiol 2006;27:2179-90.

3. Fugate JE, Claassen DO, Cloft HJ, Kallmes DF, Kozak OS, Rabinstein AA. Posterior reversible encephalopathy syndrome: associated clinical and radiologic findings. Mayo Clin Proc 2010;85:427-32. [CrossRef]

4. Bartynski WS. Posterior reversible encephalopathy syndrome, part 1: fundamental imaging and clinical features. AJNR Am J Neuroradiol 2008;29:1036-42. [CrossRef]

5. Bartynski WS, Boardman JF. Distinct imaging patterns and lesion distribution in posterior reversible encephalopathy syndrome. AJNR Am J Neuroradiol 2007;28:1320-7. [CrossRef]

6. Alhilali LM, Reynolds AR, Fakhran S. A multi-disciplinary model of risk factors for fatal outcome in posterior reversible encephalopathy syndrome. J Neurol Sci 2014;347:59-65. [CrossRef]

7. Schweitzer AD, Parikh NS, Askin G, Nemade A, Lyo J, Karimi S, et al. Imaging characteristics associated with clinical outcomes in posterior reversible encephalopathy syndrome. Neuroradiology 2017;59:379-86.

8. Gao B, Lyu C, Lerner A, McKinney AM. Controversy of posterior reversible encephalopathy syndrome: what have we learnt in the last 20 years?. J Neurol Neurosurg Psychiatry 2018;89:14-20. [CrossRef]

9. Bartynski WS. Posterior reversible encephalopathy syndrome, part 2: controversies surrounding pathophysiology of vasogenic edema. AJNR Am J Neuroradiol 2008;29:1043-9. [CrossRef]

10. Marra A, Vargas M, Striano P, Del Guercio L, Buonanno P, Servillo G. Posterior reversible encephalopathy syndrome: the endothelial hypotheses. Med Hypotheses 2014;82:619-22. [CrossRef]

11. Chen Z, Shen GQ, Lerner A, Gao B. Immune system activation in the pathogenesis of posterior reversible encephalopathy syndrome. Brain Res Bull 2017;131:93-9. [CrossRef]

12. Zampieri FG, Park M, Machado FS, Azevedo LC. Sepsis-associated encephalopathy: not just delirium. Clinics (Sao Paulo) 2011;66:1825-31.

\section{OLGU SUNUMU - ÖZET}

Yoğun bakım ünitesinde sepsisli bir hastada ensefalopatinin altında yatan

bir neden olarak posteriyor reversible ensefalopati sendromu: Olgu sunumu

\section{Dr. Günseli Orhun}

İstanbul Üniversitesi İstanbul Tıp Fakültesi, Anesteziyoloji ve Reanimasyon Anabilim Dalı, İstanbul

Posteriyor reversible ensefalopati sendromu (PRES), nörolojik bulgular ve serebral hemisferlerin posteriyor bölgelerinde vazojenik ödem ile karakterize klinik ve radyolojik bir sendromdur. Sepsis ve septik şok yakın zamanda PRES'te etiyolojik bir faktör olarak kabul edilmiştir. Yoğun bakım ünitesinde intraabdominal sepsis ve PRES'i takiben olumsuz nörolojik sonlanımı olan bir hastayı sunuyoruz. Sepsis hastalarında ensefalopatinin bir nedeni olarak PRES'in daha geniş tanınması gerekmektedir.

Anahtar sözcükler: Posterior reversible ensefalopati sendromu; prognoz; sepsis.

Ulus Travma Acil Cerrahi Derg 2020;26(2):325-327 doi: 10.14744/tjtes.2019.82668 